\title{
Glycerol production and utilization measured using stable isotopes
}

\author{
Bernard R. Landau \\ Departments of Medicine, Biochemistry, and Nutrition, Case Western Reserve University School of Medicine, Cleveland, \\ OH 44106-4951, USA
}

\begin{abstract}
The rate of appearance of glycerol in the systemic circulation is determined from the enrichment of arterial blood glycerol when labelled glycerol is infused intravenously. This value provides a good measure of whole-body lipolysis during fasting, except that arterial infusion and venous sampling, if feasible, would probably give a higher more-accurate value. Lipolysis occurs primarily in adipose tissue, although other tissues contribute, notably muscle. Measurement is based on the difference in the enrichment of the glycerol entering and leaving the tissue. Lipolysis is underestimated by the extent to which glycerol released by lipolysis does not enter the systemic circulation, as occurs when lipolysis takes place in the non-hepatic tissue of the splanchnic bed. Glycerol released into the systemic circulation is utilized mainly by liver, although kidney and muscle are also major users of glycerol. Measurement of glycerol utilization is based on the amount of labelled glycerol taken up by the tissues. Other tissues probably utilize glycerol to a smaller extent, but in total this represents a significant amount. Most glycerol taken up by liver is converted to glucose. Glucose is probably the major source of glycerol-3-phosphate used in the esterification of fatty acids by adipose tissue.
\end{abstract}

\section{Glycerol: Lipolysis: Stable isotopes}

\begin{abstract}
Whole-body production of glycerol is measured, using stable isotopes, from the enrichment in blood glycerol when ${ }^{2} \mathrm{H}$ - or ${ }^{13} \mathrm{C}$-labelled glycerol is infused. Net production or utilization (uptake) of glycerol by an organ or tissue is measured by multiplying the difference between the concentration of blood glycerol entering and leaving the organ or tissue by blood flow through the organ or tissue. When the blood glycerol is labelled, uptake of the label across the organ or tissue provides a measure of the amount of glycerol utilized by the organ or tissue.

The enrichment of the glycerol leaving the organ or tissue is less than that of glycerol entering the organ or tissue and the difference is a measure of the extent of glycerol production by the organ or tissue. (When ${ }^{3} \mathrm{H}{ }^{14} \mathrm{C}$-labelled glycerol is infused, glycerol production is determined from the specific activity of blood glycerol. The difference between the level of radioactivity in blood entering and leaving the tissue or organ is then a measure of glycerol utilized (i.e. taken up).) The methods of measurement will now be examined and examples given, particularly in human subjects after long-term fasting.
\end{abstract}

\section{Whole-body glycerol production}

The rate of appearance ( $\mathrm{Ra}$ ) of endogenous glycerol in the systemic circulation is determined by infusing ${ }^{2} \mathrm{H}$ - or ${ }^{13} \mathrm{C}$-labelled glycerol into a peripheral vein and sampling arterial blood (the venous-arterial mode). Ra at steady-state is calculated using the equation:

$$
R a=\left(\left(E_{i} / E_{a}\right)-1\right) R,
$$

where $E_{i}$ is the enrichment of the infused glycerol, $E_{a}$ is the enrichment of glycerol in the arterial blood and $\mathrm{R}$ is the rate of infusion of the glycerol (Hetenyi et al. 1983). Arterial infusion and venous sampling (the arterio-venous mode) is theoretically preferred, but is not feasible in human subjects (Katz \& Wolfe, 1988). In the rat a higher $\mathrm{Ra}$ is obtained when using the arterio-venous mode than when using the venous-arterial mode (Peroni et al. 1996). Glycerol may be produced and then utilized within an organ or tissue. For example, glycerol released by lipolysis of triacylglycerol in splanchnic adipose tissue will be cleared almost completely by the liver (Larsen, 1963; Coppack et al. 1994). This

\footnotetext{
Abbreviation: Ra, rate of appearance.

Corresponding author: Professor B. R. Landau, fax +1 216368 4927, email epc2@po.cwru.edu
} 
equivalent amount will not then appear in the systemic circulation and therefore will not be included in the Ra.

The Ra of glycerol in healthy subjects fasted long term is estimated to be about $5 \mu \mathrm{mol} / \mathrm{kg}$ body weight per min and this value is about twice that after an overnight fast (Bortz et al. 1972; Hetenyi et al. 1983; Klein et al. 1986).

\section{Regional glycerol utilization}

Utilization of glycerol during fasting is generally accepted to occur mainly in the liver, to a lesser extent in the kidney, and to minimal extents in other tissues. Thus, there is little utilization of glycerol in eviscerated animals (Larsen, 1963). In addition, glycerol kinase (EC 2.7.1.30) activity is low in tissues other than liver and kidney (Thorner \& Paulus, 1973). While phosphorylation need not be the initial step in the utilization of glycerol, enzymic activities that would catalyse alternative initial steps appear minimal (Vaughan \& Steinberg, 1965; Hagenfeldt \& Wahren, 1968). Glycerol uptake has been reported to occur in many tissues in vitro including nerve, adipose and muscle tissues, but to relatively small extents (Winkler et al. 1969).

Tracer balance techniques offer a means of quantifying glycerol utilization. Table 1 records mean concentrations and enrichments in blood glycerol when $\left[\mathrm{U}_{-}{ }^{13} \mathrm{C}_{3}\right]$ glycerol was infused for $5 \mathrm{~h}$ into subjects fasted for $60 \mathrm{~h}$ (Landau et al. 1996). The concentration of glycerol in hepatic-vein blood was $20 \%$ and the ${ }^{13} \mathrm{C}$ enrichment $25 \%$ that in the arterial blood, while the corresponding values in renal-vein blood were $50 \%$ and $75 \%$ that in arterial blood; in deepvein blood, assumed to drain muscle, the glycerol concentration was the same as that in arterial blood and the enrichment was $66 \%$ that in the arterial blood. From these data the net uptake (equated with utilization) of glycerol from the systemic circulation by the splanchnic bed, kidneys and muscle can be calculated, together with the amount of glycerol they produced that was released into the systemic circulation (Table 2).

The net balance across the splanchnic bed is calculated from the expression:

$$
\left(\text { glycerol }_{\mathrm{a}}-\text { glycerol }_{\mathrm{hv}}\right) \times \mathrm{SBF} / \text { body weight, }
$$

where glycerol $_{\mathrm{a}}$ and glycerol $_{\mathrm{hv}}$ are the concentrations of glycerol in arterial and hepatic vein blood respectively and SBF is splanchnic blood flow. Using the data in Table 1 the net glycerol uptake by the splanchnic bed is $1.4 \mu \mathrm{mol} / \mathrm{kg}$ per

Table 1. Glycerol concentration and ${ }^{13} \mathrm{C}$ enrichments of glycerol in blood collected from blood vessels on infusion of $\left[\mathrm{U}^{-13} \mathrm{C}_{3}\right]$ glycerol in subjects fasted for $60 \mathrm{~h}$ * (From Landau et al. 1996)

\begin{tabular}{lcc}
\hline $\begin{array}{l}\text { Blood } \\
\text { vessel }\end{array}$ & $\begin{array}{c}\text { Glycerol concentration } \\
(\mu \mathrm{M} / \mathrm{l})\end{array}$ & $\begin{array}{c}{ }^{13} \mathrm{C} \text { enrichment of glycerol } \\
(\%)\end{array}$ \\
\hline Brachial artery & 94 & $6 \cdot 3$ \\
Hepatic vein & 18 & $1 \cdot 4$ \\
Renal vein & 49 & $4 \cdot 8$ \\
Deep vein & 95 & $4 \cdot 1$ \\
\hline
\end{tabular}

* The average blood flow through the splanchnic bed was 1.5 litre/min 1.4 litre/min through the kidneys, and estimated to be 1.3 litre/min through total-body muscle. The rate of appearance of glycerol averaged $5.1 \mu \mathrm{mol} / \mathrm{kg}$ body weight per min. Average weight of the subjects was $82 \mathrm{~kg}$ min. The unlabelled glycerol released into the circulation that was produced within the splanchnic bed is:

$$
\left(\text { glycerol }_{\mathrm{hv}} \times\left(\mathrm{E}_{\mathrm{a}}-\mathrm{E}_{\mathrm{hv}}\right) / \mathrm{E}_{\mathrm{a}}\right) \times \mathrm{SBF} / \text { body weight, }
$$

where $E_{\mathrm{a}}$ and $\mathrm{E}_{\mathrm{hv}}$ are the enrichments in arterial and hepaticvein glycerol respectively. Using the data from Table 1 the rate of release from the splanchnic bed is $0.3 \mu \mathrm{mol} / \mathrm{kg}$ per min. The total amount of glycerol from the systemic circulation that was taken up by the splanchnic bed is:

$\left(\left(\right.\right.$ glycerol $_{\mathrm{a}} \times \mathrm{E}_{\mathrm{a}}-$ glycerol $\left._{\mathrm{hv}} \times \mathrm{E}_{\mathrm{hv}}\right) /$ glycerol $\left._{\mathrm{a}} \times \mathrm{E}_{\mathrm{a}}\right) \times$ glycerol $_{\mathrm{a}} \times \mathrm{SBF} /$ body weight, i.e. $1 \cdot 7 \mu \mathrm{mol} / \mathrm{kg}$ per min.

Presumably, therefore, the liver utilized $100(1 \cdot 7 / 5 \cdot 1)=30 \%$ of the glycerol entering the systemic circulation, the kidneys about $20 \%$, and muscle $10 \%$. In dogs which had been fasted long-term the results were similar (Previs et al. 1996). Balance studies have suggested that there is uptake of glycerol by muscle of human subjects fasted overnight, although results have been variable (Frayn et al. 1991). Sacchetti \& van Hall (1999) infused $\left[{ }^{2} \mathrm{H}_{5}\right]$ glycerol with a primer into subjects at rest for $2 \mathrm{~h}$ and then during $2 \mathrm{~h}$ of exercise. There was a release of glycerol as well as glycerol uptake by the leg, both of which increased with exercise. Coppack et al. (1999) have also reported uptake of glycerol by muscle. Hagenfeldt \& Wahren (1968) observed uptake of $\left[1-{ }^{14} \mathrm{C}\right]$ glycerol and oxidation to ${ }^{14} \mathrm{CO}_{2}$.

The site(s) of utilization of the $40 \%$ of the Ra presumably remaining is unknown. Klein et al. (1996) and Coppack et al. (1999) found no uptake of glycerol across the adipose tissue. Elia et al. (1993) and Kurpad et al. (1994) found uptake and dilution of $\left[{ }^{2} \mathrm{H}_{5}\right]$ glycerol across the adipose tissue and muscle. However, infusion was only for $1 \mathrm{~h}$, so that steady-state may not have been achieved. In the study of Samra et al. (1999) subjects fasted overnight were infused with $\left[{ }^{2} \mathrm{H}_{5}\right]$ glycerol for $7 \mathrm{~h}$ and arterial and adipose venous glycerol concentrations and enrichments during the last $6 \mathrm{~h}$ were determined. The measurements are in accordance with glycerol uptake by subcutaneous adipose tissue. In individuals fasted overnight the mean uptake of glycerol across brain was about $0.25 \mu \mathrm{mol} / \mathrm{kg}$ per min, but not significantly different from zero (Ahlborg \& Wahren, 1972). Uptake by pulmonary tissues remains a possibility, but because of the large blood flow through the lungs, uptake could not be determined with any confidence (Landau et al. 1996). There was no demonstrable change in the concentration of glycerol across the lungs of fasted dogs (Borchgrevink \& Havel, 1963).

Table 2. Net glycerol uptake, glycerol production (release into the systemic circulation), and utilization ( $\mu \mathrm{mol} / \mathrm{kg}$ body weight per min) by the splanchnic bed, kidneys and muscle*

\begin{tabular}{lccc}
\hline Site & Net uptake & Production & Utilization \\
\hline Splanchnic bed & 1.4 & 0.3 & 1.7 \\
Kidneys & 0.8 & 0.2 & 1.0 \\
Muscle & 0.0 & 0.5 & 0.5 \\
Total & 2.2 & 1.0 & 3.2
\end{tabular}

*Values were calculated from data shown in Table 1 (for details of calculations, see p. 974). 


\section{Regional glycerol production}

Of the $5 \cdot 1 \mu \mathrm{mol}$ glycerol $/ \mathrm{kg}$ body weight per min appearing in the systemic circulation, $1.0 \mu \mathrm{mol} / \mathrm{kg}$ body weight per min, i.e. $20 \%$, was produced by the splanchnic bed, kidneys and muscle. This finding is in accordance with lipolysis of triacylglycerol in adipose cells being the major source of glycerol in the fasted state. As a result of the uptake by the liver, more glycerol was produced in the splanchnic bed than was released. To a lesser extent more glycerol must have been produced than was released by kidney and muscle.

Essentially all glycerol production in the splanchnic bed appears to originate from omental and mesenteric adipose tissue (Jensen \& Johnson, 1996). However, in postoperative patients fasted overnight there was no net release of glycerol into the portal circulation (Bjorkman et al. 1990). In addition, evidence for minimal production (at most) by liver was reported by Basso \& Havel (1970), who infused $\left[1-{ }^{14} \mathrm{C}\right]$ palmitate into fasted dogs and found that the specific activity of free fatty acid leaving the liver was the same as that entering the liver. In the perfused liver, glycerol formation by hydrolysis of glycerol-3-phosphate has been suggested to occur (Previs et al. 1995), but this process was not found to occur in human subjects (Diraison \& Beylot, 1998). In fasted dogs less than $10 \%$ of the free fatty acid flux has been estimated to be derived from mesenteric lipolysis (Basso \& Havel, 1970; Wasserman et al. 1989). However, in the subjects fasted for $60 \mathrm{~h}$, assuming glycerol was not taken up by the non-hepatic splanchnic tissues and dilution of the enrichment of the glycerol entering the splanchnic bed occurred from glycerol released from the non-hepatic splanchnic tissues, glycerol production by those tissues was:
$(94 \times 1.5 \times((6.3-1.4) / 6.3)) / 82=1.3 \mu \mathrm{mol} / \mathrm{kg}$ per min, i.e. glycerol ${ }_{a} \times \operatorname{SBF}\left(\left(E_{a}-E_{h v}\right) / E_{a}\right) /$ body weight,

i.e. about $30 \%$ of the Ra of glycerol, even though only $0.3 \mu \mathrm{mol} / \mathrm{kg}$ per min was released into the systemic circulation.

\section{Glycerol and Re-esterification}

Whole-body glycerol production, measured as the Ra, has been taken as the measure of whole-body lipolysis. The amount of fatty acid released into the circulation would therefore be three times the rate of glycerol production, i.e. triacylglycerol $\rightarrow$ glycerol + three fatty acids, which is supported by measurements of free fatty acid turnover (Klein et al. 1986; Coppack et al. 1994). However, measurements of glycerol and fatty-acid turnover, and the amount of fatty acid oxidized (as determined by indirect calorimetry) during fasting have shown that the level of fatty acids released into the circulation is greater than that utilized (Klein et al. 1986; Bonadonna et al. 1990; Wolfe et al. 1990; Campbell et al. 1992; Wolfe, 1992a,b). During long-term fasting 60-70 \% of the fatty acids released are estimated to be re-esterified. Re-esterification has been assumed to occur only in the liver (Hellerstein et al. 1993), but there is evidence that the major site is the extra-hepatic tissues (Diraison \& Beylot, 1998). Balance studies indicate fatty acid uptake by the splanchnic bed may represent only about $25 \%$ of the amount re-esterified during long-term fasting (Landau et al. 1996). The major site of this re-esterification is presumably adipose tissue, with some re-esterification occurring in muscle (Figs. 1 and 2).

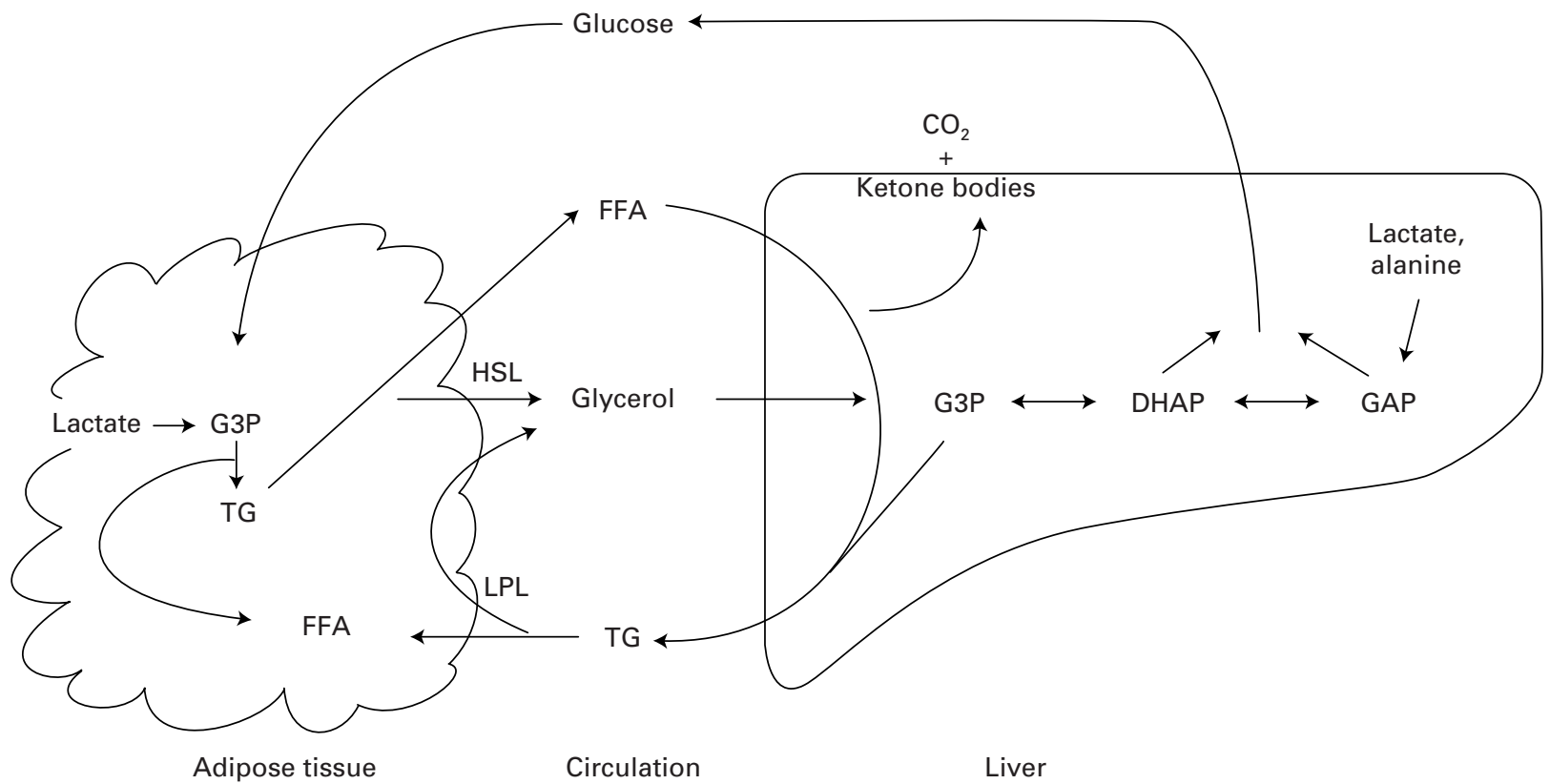

Fig. 1. Relationship between liver and adipose tissue with respect to pathways of glycerol, free fatty acid (FFA), triacylglycerol (TG), and glycerol-3-phosphate (G3P) metabolism. DHAP, dihydroxyacetone-3-phosphate; GAP, glyceraldehyde-3-phosphate; HSL, hormone-sensitive lipase; LPL, lipoprotein lipase (EC 3.1.1.34). 


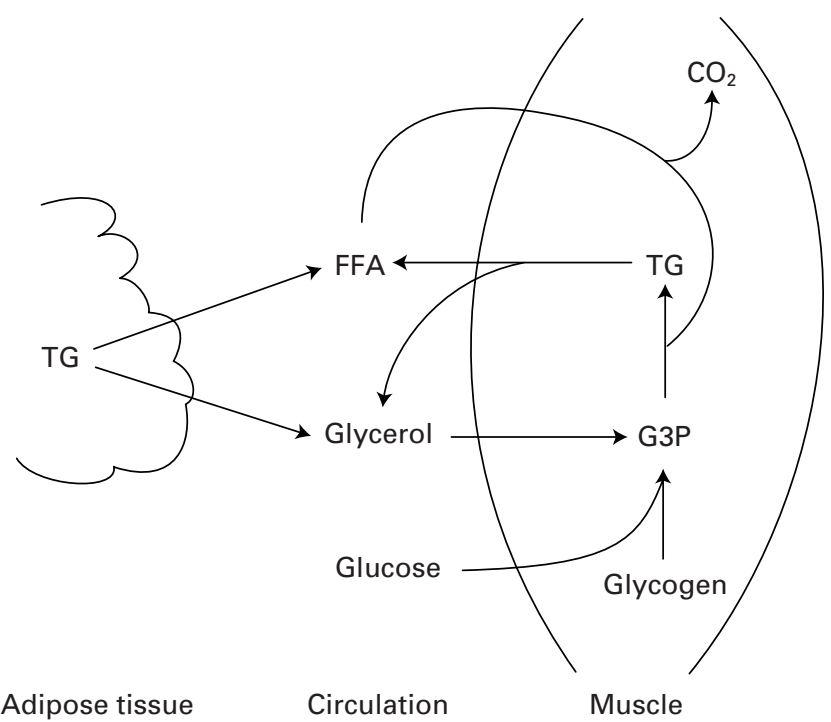

Fig. 2. Relationship between muscle and adipose tissue with respect to pathways of glycerol, free fatty acid (FFA) triacylglycerol (TG) and glycerol-3-phosphate (G3P) metabolism.

The following calculations illustrate the implications of the re-esterification. Since after $60 \mathrm{~h}$ of fasting the Ra of glycerol is $5 \mu \mathrm{mol} / \mathrm{kg}$ per min (measured by infusing labelled glycerol), $15 \mu \mathrm{mol}$ free fatty acid/kg per min are released into the circulation and about $10 \mu \mathrm{mol} / \mathrm{kg}$ per min are re-esterified. About $25 \%$, i.e. $2.5 \mu \mathrm{mol} / \mathrm{kg}$ per $\mathrm{min}$, is then re-esterified in the liver. Since essentially all glycerol entering the splanchnic bed is removed during a single passage, the $0.8 \mu \mathrm{mol}$ glycerol-3-phosphate $/ \mathrm{kg}$ per min used in re-esterification in the liver is essentially unlabelled (see glycerol synthesis). The fatty acids which are present in triacylglycerol thus formed and released into the circulation are then presumably mainly deposited as triacylglycerol in adipose tissue. Uptake of triacylglycerol across subcutaneous abdominal tissue in subjects fasted overnight has been demonstrated by arterio-venous balance (Frayn et al. 1993). Hydrolysis of this triacylglycerol to fatty acid and glycerol is catalysed by lipoprotein lipase (EC 3.1.1.34). The fatty acid released from this triacylglycerol is the same fatty acid that has been esterified with glycerol on two occasions, first before lipolysis occurred and second when the re-esterified fatty acid was redeposited in adipose tissue. The result, assuming no further processing occurs, would be a value for fatty acid $\mathrm{Ra}$ : glycerol $\mathrm{Ra}$ of $<3$ (i.e. approximately $100(0 \cdot 8 / 5)=16 \%$ less $)$. However, if some free fatty acids from the splanchnic bed are released into the circulation, the ratio would be $>3$. The $\mathrm{Ra}$ for glycerol across the subcutaneous adipose tissue has been estimated to be twice the amount of glycerol released, when determined by arterio-venous balance (Kurpad et al. 1994). However, glycerol released into the capillaries by the action of lipoprotein lipase will be included in the $\mathrm{Ra}$ of glycerol, but it will result in the underestimation of glycerol released when this is determined using the balance technique because the hydrolysis occurs after arterial sampling. The glycerol released into the capillaries would dilute the enrichment of labelled glycerol passing through the tissue, while raising the concentration of the glycerol in venous blood leaving the tissue and hence decreasing the arterio-venous difference.

\section{Glycerol synthesis}

When labelled glycerol is infused, the glycerol used for re-esterification in the liver is essentially unlabelled, because the labelled glycerol-3-phosphate formed equilibrates with dihydroxyacetone-3-phosphate and glyceraldehyde-3-phosphate (intermediates in the conversion of the other gluconeogenic substrates, e.g. unlabelled lactate and alanine, to glucose). Experimental evidence for this process was obtained when ${ }^{2} \mathrm{H}_{2} \mathrm{O}$ was ingested by normal subjects fasted for $60 \mathrm{~h}$. The enrichment of the two $\mathrm{H}$ bound to C- 6 of blood glucose was compared with the enrichment of the two $\mathrm{H}$ bound to C-3 of blood glycerol (Jensen et al. 1999). If isotopic equilibration of glyceraldehyde-3phosphate with glycerol-3-phosphate was complete and all the glycerol in the blood was synthesized from glycerol-3phosphate in liver, the enrichments at C-3 of glycerol and at C-6 of glucose should be the same. The enrichment at C-3 was 17 (SE 3) \% ( $n$ 4) that at C-6. Thus, about $17 \%$ of the $5 \mu \mathrm{mol}$ glycerol $/ \mathrm{kg}$ per min entering the systemic circulation (i.e. $0.8 \mu \mathrm{mol} / \mathrm{kg}$ per min) was synthesized in the liver rather than released from triacylglycerol stores. This amount is in agreement with the $0.8 \mu \mathrm{mol}$ glycerol $/ \mathrm{kg}$ per min estimated to be released during re-esterification of the fatty acids. In a study using labelled glycerol and glucose, $17 \%$ of the glycerol in the circulation of rats fasted for $24 \mathrm{~h}$ was attributed to synthesis (DeFreitas \& Depocas, 1970).

Glycerol-3-phosphate required for the esterification of the fatty acids in adipose tissue cannot be derived from glycerol to any significant extent. Thus, as previously noted, Klein et al. (1996) could not detect uptake of glycerol by adipose tissue. Based on the low activity of glycerol kinase, glycerol utilization by adipose tissue has been estimated to account for $<1 \%$ of the glycerol production (Kurpad et al. 1994). In order to esterify the $10 \mu \mathrm{mol}$ fatty acids calculated to be cycled in a subject fasted for $60 \mathrm{~h}, 1.67 \mu \mathrm{mol}$ glucose would need to be converted to glycerol-3-phosphate (about $20 \%$ of the glucose production for a human subject fasted for $60 \mathrm{~h}$ ). Approximately $80 \%$ of the glycerol taken up by the liver (and kidney) is converted to glucose in a human subject fasted for $60 \mathrm{~h}$ (Landau et al. 1996). A glucoseglycerol cycle then appears to be active, with glycerol from adipose tissue triacylglycerol being converted to glucose in liver (and kidney) and the glucose being converted to glycerol-3-phosphate in adipose tissue to form triacylglycerol. The uptake of glucose by adipose tissue would have to occur in the presence of a high blood glucagon:insulin value. Alternatively, the glycerol-3phosphate could be formed by glyceroneogenesis from lactate and/or alanine (Reshef et al. 1970; Hanson et al. 1971). However, blood flow through adipose tissue is not sufficient to provide these substrates in sufficient quantities for them to make a major contribution. In addition, net production of lactate has been reported in adipose tissue of human subjects fasted for $60 \mathrm{~h}$ (Landau et al. 1996), and also in adipose tissue from rats fasted for $48 \mathrm{~h}$ (Newby et al. 1990). Glycerol-3-phosphate used in esterification in muscle 
could be derived from muscle glycogen, as well as from glucose (Fig. 2).

\section{References}

Ahlborg G \& Wahren J (1972) Brain substrate utilization during prolonged exercise. Scandinavian Journal of Clinical and Laboratory Investigation 29, 397-402.

Basso LV \& Havel RJ (1970) Hepatic metabolism of free fatty acids in normal and diabetic dogs. Journal of Clinical Investigation 49, 5337-5347.

Bjorkman O, Eriksson LS, Nyberg B \& Wahren J (1990) Gut exchange of glucose and lactate in basal state and after oral glucose ingestion in postoperative patients. Diabetes 39, 747-751.

Bonadonna RC, Groop LC, Zych K, Shank M \& DeFronzo RA (1990) Dose-dependent effect of insulin on plasma free fatty acid turnover and oxidation in humans. American Journal of Physiology 259, E736-E750.

Borchgrevink CF \& Havel RJ (1963) Transport of glycerol in human blood. Proceedings of the Society for Experimental Biology and Medicine 113, 946-949.

Bortz WM, Paul P, Haff AC \& Holmes WL (1972) Glycerol turnover and oxidation in man. Journal of Clinical Investigation 51, 1537-1546.

Campbell PJ, Carlson MG, Hill JO \& Nurjhan N (1992) Regulation of free fatty acid metabolism by insulin in humans: role of lipolysis and reesterification. American Journal of Physiology 263, E1063-E1069.

Coppack SW, Jensen MD \& Miles JM (1994) In vivo regulation of lipolysis in humans. Journal of Lipid Research 35, 177-193.

Coppack SW, Persson M, Judd RL \& Miles JM (1999) Glycerol and nonesterified fatty acid metabolism in human muscle and adipose tissue in vivo. American Journal of Physiology 276, E233-E240.

DeFreitas AS \& Depocas F (1970) Glyceride-glycerol release and the interconversion of glucose and glycerol in normal and fasted rats. Canadian Journal of Physiology and Pharmacology 48, 561-568.

Diraison F \& Beylot M (1998) Role of human liver reesterification in triglyceride secretion and in FFA reesterification. American Journal of Physiology 274, E321-E327.

Elia M, Khan K, Calder G \& Kurpad A (1993) Glycerol exchange across the human forearm assessed by a combination of tracer and arteriovenous exchange techniques. Clinical Science 84, 99-104

Frayn KN, Coppack SW \& Humphreys SM (1991) Glycerol and lactate uptake in human forearm. Metabolism 40, 1317-1319.

Frayn KN, Coppack SW \& Humphreys SM (1993) Subcutaneous adipose tissue metabolism studied by local catheterization. International Journal of Obesity and Related Metabolic Disorders 17, S18-S21.

Hagenfeldt L \& Wahren J (1968) Human forearm metabolism during exercise. Uptake, release and oxidation of individual fatty acids and glycerol. Scandinavian Journal of Clinical and Laboratory Investigation 21, 263-276.

Hanson RW, Patel MS, Reshef L \& Ballard FJ (1971) The role of pyruvate carboxylase and P-enolpyruvate carboxykinase in adipose tissue. In Regulation of Gluconeogenesis, pp. 255-276 [HD Soling and B Williams, editors]. Stuttgart: G. Theme Verlag.

Hellerstein MK, Neese RA \& Schwarz J-M (1993) Model for measuring absolute rates of hepatic de novo lipogenesis and reesterification of free fatty acids. American Journal of Physiology 265, E814-E820.
Hetenyi G Jr, Perez G \& Vranic M (1983) Turnover and precursorproduct relationships of nonlipid metabolites. Physiological Reviews 68, 606-667.

Jensen MD, Chandramouli V, Schumann WC, Ekberg K, Wahren J \& Landau BR (1999) Sources of blood glucose during long term fasting. Diabetes 48, Suppl. 1, A68.

Jensen MD \& Johnson CM (1996) Contribution of leg and splanchnic free fatty acid (FFA) kinetics to postabsorptive FFA flux in men and women. Metabolism 45, 662-666.

Katz J \& Wolfe RR (1988) On the measurement of lactate turnover in humans. Metabolism 37, 1078-1080.

Klein S, Coppack S, Chinkes D \& Villanueva-Meyer J (1996) Regional transendothelial glycerol kinetics in humans. FASEB Journal 10, A520.

Klein S, Young VR, Blackburn GL, Bistrian BR \& Wolfe RR (1986) Palmitate and glycerol kinetics during brief starvation in normal weight young adult and elderly subjects. Journal of Clinical Investigation 78, 928-933.

Kurpad A, Khan K, Calder AG, Coppack S, Frayn K, Macdonald I \& Elia M (1994) Effect of noradrenaline on glycerol turnover and lipolysis in the whole body and subcutaneous adipose tissue in humans in vivo. Clinical Science 86, 177-184.

Landau BR, Wahren J, Previs SF, Ekberg K, Chandramouli V \& Brunengraber H (1996) Glycerol production and utilization in humans: sites and quantitation. American Journal of Physiology 271, E1110-E1117.

Larsen JA (1963) Elimination of glycerol as a measure of the hepatic blood flow in the cat. Acta Physiologica Scandinavica 57, 224-234.

Newby FD, Wilson LK, Thaker SV \& Girolamo M (1990) Adipocyte lactate production remains elevated during refeeding after fasting. American Journal of Physiology 259, E865-E871.

Peroni O, Large V, Odeon M \& Beylot M (1996) Measuring glycerol turnover, gluconeogenesis from glycerol, and total gluconeogenesis with $\left[2-{ }^{13} \mathrm{C}\right] \mathrm{glycerol}$ : role of the infusionsampling mode. Metabolism 45, 897-901.

Previs SF, Fernandez CA, Yang D, Soloviev MV, David F \& Brunengraber H (1995) Limitations of the mass isotopomer distribution analysis of glucose to study gluconeogenesis. Substrate cycling between glycerol and triose phosphates in liver. Journal of Biological Chemistry 270, 19806-19815.

Previs SF, Martin SK, Hazey JW, Soloviev MV, Keating AP, Lucas D, David F, Koshy J, Kirschenbaum DW, Tserng KY \& Brunengraber H (1996) Contributions of liver and kidneys to glycerol production and utilization in the dog. American Journal of Physiology 271, E1118-E1124.

Reshef L, Hanson RW \& Ballard FJ (1970) A possible physiological role for glyceroneogenesis in rat adipose tissue. Journal of Biological Chemistry 245, 5979-5984.

Sacchetti M \& van Hall G (1999) Glycerol exchange in human skeletal muscle at rest and during exercise. Proceedings of the Nutrition Society 58, 164A.

Samra JS, Clark ML, Humphreys SM, Bannister PA, Summers LKM, MacDonald IA \& Frayn KN (1999) Evidence for glycerol uptake by subcutaneous adipose tissue. Proceedings of the Nutrition Society 58, 164A.

Thorner JW \& Paulus H (1973) Glycerol and glycerate kinases. In The Enzymes, pp. 487-511 [PD Boyer, editor]. New York: Academic Press.

Vaughan M \& Steinberg D (1965) Glyceride biosynthesis, glyceride breakdown and glycogen breakdown in adipose tissue: mechanisms and regulation. In Handbook of Physiology. Section 5. Adipose Tissue, pp. 239-251 [AE Renold and GF Cahill, editors]. Washington, DC: American Physiological Society. 
Wasserman DH, Lacy DB, Goldstein RE, Williams PE \& Cherrington AD (1989) Exercise-induced fall in insulin and increase in fat metabolism during prolonged muscular work. Diabetes 38, 484-490.

Winkler B, Steele R \& Altszuler N (1969) Relationship of glycerol uptake to plasma glycerol concentration in the normal dog. American Journal of Physiology 216, 191-196.

Wolfe RR (1992a) Radioactive and Stable Isotope Tracers in Biomedicine. New York: Wiley-Liss.
Wolfe RR (1992b) Assessment of substrate cycling in humans using tracer methodology. In Energy Metabolism: Tissue Determinants and Cellular Corollaries, pp. 495-524 [J Kinney and HN Tucker, editors]. New York: Raven Press.

Wolfe RR, Klein S, Carraro F \& Weber J-M (1990) Role of triglyceride-fatty acid cycle in controlling fat metabolism in humans during and after exercise. American Journal of Physiology 258, E382-E389. 